\title{
Learning Process of Drawing Manga Comics With E-Learning Models in Non-Formal Schools OHAYO Drawing School Surakarta
}

\author{
Galuh Gussantoko ${ }^{1}$, Slamet Subiyantoro ${ }^{2}$, Endang Widiyastuti ${ }^{3}$ \\ ${ }^{1}$ Masters Program in Arts Education, Sebelas Maret University, Surakarta, Indonesia. \\ ${ }^{2,3}$ Faculty of Teacher Training and Education, Sebelas Maret University, Surakarta, Indonesia. \\ Email: galuhgussantoko@gmail.com
}

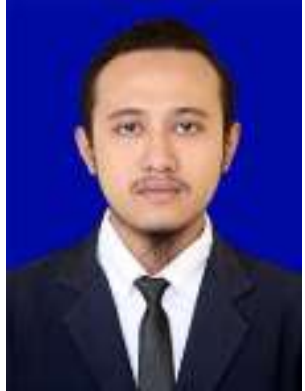

GALUH GUSSANTOKO

Keywords:

Learning,

E-learning Methods,

Manga Comics,

Non-Formal Schools

\begin{abstract}
A B S T R A C T
This research discusses the learning process of drawing manga comics using e-learning models in non-formal schools. Some kids have talent and willpower but there is no place to channel that talent. As a result, children with such talents become less creative. In the absence of a place to channel talent, the child will do activities to cross the walls, textbooks, etc. In addition, during the covid-19 pandemic, all activities are carried out through online or internet platforms that cause children to learn face-to-face. This research methodology uses descriptive qualitative methods by describing the learning process with the e-learning model available at OHAYO Drawing School Surakarta. The purpose of this research is to explain the process of drawing manga comics done with the e-learning model during the covid-19 pandemic period. Data collection on this study by way of in-depth interviews, observations, and documentation. The result of this study is that the model of drawing manga comics using the $e$ learning model is suitable for use in nonformal schools. With the learning model, children can still channel talents and hobbies so that the child's creativity continues to grow and develop despite being in the covid-19 pandemic.
\end{abstract}




\section{International Journal of}

Advanced Multidisciplinary Scientific Research (IJAMSR) ISSN:2581-4281

\section{Introduction}

Learning is a set of actions designed to support the student learning process, taking into account external events that play a role in the series of internal events that students experience (Winkel, 1991). According to Yamin \& Maisah (2009:164), learning is a concept that can develop in line with the demands of educational outcome needs related to the advancement of science and technology inherent in the development of human resource quality.

Learning is essentially one part of education. With the learning process, students or students will obtain and absorb and receive all information that has been conveyed/provided by the teacher. Therefore, through learning, students will obtain a science that can change behavior through the experience.

Learning can also foster creativity in children, one of which is through the learning of fine arts. Fine arts learning is an effort that makes students work fine art, through the process of expressing with graphic media, fields, and colors (Sudarmaji in Utomo, 2009: 6). Thus, art learning one of the fine arts can make students become creative children because in fine arts learning students can express themselves according to their imagination.

Based on data obtained through observation, one of the educational institutions engaged in non-formal learning is the OHAYO Drawing School located in Surakarta City of Central Java Province. The educational institution becomes a means of supporting the needs of children in the allocation of talent, as a means to learn to draw for children who have interests and hobbies related to art outside of formal school, as well as the formation of creativity of children. According to Munandar (1995:25), creativity is a common ability to create something new. Ohayo Drawing School Surakarta education institution is located at $\mathrm{Jl}$. D.I. Panjaitan No.52, Rejosari RT 04 RW 14 Gilingan Banjarsari, Solo, Central Java 57134. It was founded by Oscar Sumarli, S.E and Widyana Susanti, S.E and managed by Darwin Ardhi Nata (Observation, 04 August 2020).

Based on the data obtained through interviews, OHAYO Drawing School is a place to contribute education and help the process of developing children's creativity to be a confident, clever, and superior person in the field of non-academic in accordance with the criteria of child development in the world of 
fine arts (Interview of the organizer of the Institute, 05 August 2020). In line with that expressed by Bachtiar, the goal of nonformal education is to develop harmoniously, and balanced intelligence attitudes, creativity, and skills to improve the quality of living rates of citizens of the nation and country (Bachtiar, 1985 in Sutarto, 2007:4). Thus, it can be said that non-formal education in OHAYO Drawing School can foster attitude intelligence as well as foster creativity in children through drawing learning.

The next data obtained in the field during observation is parents' concern for the child about scribble activities that do not fit into place. many parents complain because their children like to doodle walls at home and draw on textbook paper. Thus, parents of children have initiatives to send their children to drawing school to channel their hobbies so that the activities of scribbling the wall are channeled through the school drawing, and often assume that their child has a talent for drawing. Thus, if this is not addressed then the development and growth of creativity in the child will not grow and develop to the maximum. That's where the child's parents chose to send their child to OHAYO Drawing
School Surakarta (Observation, 04 August 2020).

In addition, during the covid-19 pandemic, all activities are carried out through online platforms or the internet which causes children to be unable to learn face-to-face because it is still very dangerous for their health. The elearning model conducted by OHAYO Drawing School Surakarta allows children to still be able to learn to draw and at the same time channel their talents and hobbies.

Based on the exposure and phenomena that occur in the field, the phenomenon deserves to be reviewed by describing the learning process of drawing manga comics with e-learning models in the nonformal school OHAYO Drawing School Surakarta.

\section{Methods and Materials:}

This research is the result of data collection obtained in the nonformal School, OHAYO Drawing School Surakarta. The data obtained in this study through: (1) Observations made in this study are that researchers play a passive role by coming to observe, see and listen directly to the activities that take place in the OHAYO Drawing School by recording and describing. (2) Interviews in this study are in a 


\section{International Journal of Advanced Multidisciplinary Scientific Research (IJAMSR) ISSN:2581-4281}

structured, mixed, and in-depth way, the target object of the source is the manager of OHAYO, OHAYO teacher, and parents of OHAYO students. (3) Documentation by collecting data in the form of photographs of documents and written documents in the field during the learning process.

The data analysis technique used is interactive analysis. The basic principle of interactive analysis is that all activities or activities of the analysis are carried out in conjunction with the processor time of data collection (Sutopo, 2006:119-121). Based on the type of research used is qualitative descriptive, then from the data collected will be analyzed using interactive analysis that is by describing the results of the study in the form of sentences so that thus the researcher will elaborate in depth the results of the study according to the circumstances that occurred in the field. In this study, researchers used interactive analysis techniques to conclude. Because there is data from the research in the form of written sentences and will be outlined in an outline and drawn conclusions.

\section{Results and Discussion:}

This study uses a descriptive qualitative type that describes and describes the learning of drawing manga comics carried out in nonformal schools. Bogdan and Taylor (1975) (in Moeleong, 2017:5) defines qualitative research as a research process that produces descriptive data in the form of written or oral words from people and observable behavior. This study discussed the learning process of drawing manga comics using the e-learning model in the nonformal school OHAYO Drawing School Surakarta.

\section{Learning Process}

Learning is an effort to guide and direct the learning experience to students and is usually directly in official or formal situations. According to Dimyati and Mudjiono (2006: 297), learning is a programmatic teacher activity in instructional design, to make students learn actively, which emphasizes the provision of learning resources.

Learning conducted in OHAYO Drawing School refers to the learning module that has been provided. In the learning process, the teacher prepares the material to be given to the student. The learning process is to use the online/e-learning system through a zoom meeting on a smartphone. Online learning was carried out because the activity was during the covid-19 pandemic which is still not possible 
to have a meeting in person between teachers and students. Although the learning is carried out in non-formal schools and through online/e-learning, it is still systematically constructed from the time of implementation, as well as material form. By using a smartphone, learning runs effectively.

The learning process conducted at OHAYO Drawing School uses drill learning methods. The method is used by teachers to train students repeatedly until they become proficient and able to create manga comic images. Because the school is engaged in the field of fine arts and the priority is skills (working practice) then repeated training becomes a suitable model to be applied to the learning process. So by studying at the nonformal school, students will be formed in terms of skill and creativity. This is in accordance with Fathurrohman (2017) the drill method is generally used to obtain some dexterity or skill from the material that has been studied (Fathurrohman, 2017:354).

The acquisition of comic drawings from the student's work required 11 (eleven) meetings. The stages of the learning process will be described in the following table.

Table 1. Learning stages of creating manga comics.

\begin{tabular}{|c|c|}
\hline Meeting & Stages \\
\hline 1 & Development of arsenic techniques and imitating images of objects. \\
\hline 2 & Draw inanimate characters and living objects along with shade. \\
\hline 3 & Create indentation shapes on the drapery fabric. \\
\hline 4 & Create a shaded effect on the face and hair. \\
\hline 5 & Draw the same characters consistently and lighting effects \\
\hline 6 & $\begin{array}{l}\text { Apply coloring techniques using color pencils and create outlines using drawing pens and } \\
\text { markers }\end{array}$ \\
\hline 7 & Apply various coloring techniques using watercolors. \\
\hline 8 & The effect of the lines applied to the character object. \\
\hline 9 & The giving of word balloons and the way they are placed in comics. \\
\hline 10 & The application of these techniques became a comic story. \\
\hline
\end{tabular}




\section{International Journal of}

Advanced Multidisciplinary Scientific Research (IJAMSR) ISSN:2581-4281

Providing motivation and appreciation to students is always done by teachers in the learning process by using words of praise towards the work of students that have been created, this aims to make students more excited in the learning process. Besides, mentors/teachers provide students with the opportunity to work according to their imagination. By providing such motivation and freedom, students will be confident and not ashamed to express themselves so that the creativity that the child has will be formed and developed well. Thus, to form creativity, students need to be given freedom of work as well as freedom of expression. This is in line with Endang's opinion (2012:139) in his journal, the touch of strengthening and motivation by teachers towards the results of the students' images can increase his confidence in making the form (motif/chart) of the image. So that students can express freely in making shapes (motifs/ charts) according to the theme that appears in free drawing activities (Endang, 2012:139).

The process of creating manga comics is first given instructions to learn the technical stages in table 1. This stage is the basic stage in the creation of manga comics so that the resulting comics look good. Besides, this stage is also to facilitate students in the process of creating manga comics as well as the introduction and practice of making various forms of objects that will be applied and combined into manga comic forms.

The work produced by students from the learning process varies. Students are able to create and apply line shapes applied to an image object. From the technical stages that have been taught by teachers, students are able to create various forms of characters, forms of expression, forms of motion, balloon shapes of words, and sentences of dialogue applied to comics according to their creativity so that the resulting shapes are various, different and unique. This is reinforced by the opinion (Barbot, 2011 in the journal Willemsen) creativity which is a thought activity that differs from one thought to another (Willemsen, 2019:2). From that opinion, it is very clear that a child who has been able to create and bring up new and different forms that come from within his mind can be categorized as a creative child.

Furthermore, in terms of the story made also varies. Although some students make object figures such as Japanese manga but have a difference that is in the story. The story is 


\section{International Journal of}

Advanced Multidisciplinary Scientific Research (IJAMSR) ISSN:2581-4281

different from the story in both Japan and Korea. As revealed by (Brenner, 2007) the manga covers works in various genres such as action, adventure, business and commerce, science fiction, erotica.

The stories produced by OHAYO Drawing School students tend to raise stories of local wisdom in their area of residence such as playing hide and seek, vacationing to grandma's house, please help, looking for ghosts, and so on. Thus, the child's creativity will arise when the child is given the freedom to express, and it is clear that the student looks creative judging by the resulting form of comic story and brings up something new. This is reinforced by Munandar's opinion (1995:25), creativity is a common ability to create something new, as the ability to give new ideas.

Although the manga comics are from Japan and Korea, students at these nonformal schools can create manga comics that are different from Japanese and Korean manga comics.

\section{E-Learning Model Learning}

The selection of learning models should have considerations. For example, the defense material, the level of cognitive development of students, and the facilities or facilities available, so that the goals of learning (art learning) that have been set can be achieved. The purpose of learning in the nonformal school OHAYO Drawing School Surakarta is to contribute education and help the process of developing the creativity of children in order to be a confident, clever, and superior person in the field of non-academic and in accordance with the criteria of child development (Interview with Mr. Darwin as the manager of OHAYO Drawing School, August 5, 2020). Thus, the purpose of learning in OHAYO is strengthened by Iryanti's opinion in his journal, the purpose of arts education can be a vehicle for the development of the nation's culture towards the formation of human qualities and creative lifestyles through exercises (Iryanti, 2001:42-43).

The use of the right learning model can encourage students' growing enjoyment of the lesson, increase motivation in doing tasks, and make it easier for students to understand lessons so as to enable students to achieve better learning outcomes. This is in line with Winataputra 's opinion (2001) in Sugiyanto (2008:7) the learning model is a conceptual framework that describes systematic 
Vol 3, Issue 10, 2020 Imfact Factor:2.58 DOI: https://doi.org/10.31426/ijamsr.2020.3.10.3814

\section{International Journal of \\ Advanced Multidisciplinary Scientific Research (IJAMSR) ISSN:2581-4281}

procedures in organizing learning experiences to achieve certain learning goals.

The learning model used in Ohayo drawing schools is to use e-learning/online methods. ELearning is a learning system that utilizes electronic media as a tool to help to learn activities (Daryanto, 2010:168). Thus, OHAYO Drawing School students do not need to come and sit in class to perform and listen to the learning materials delivered by the teacher directly but can be listened to and noticed from their respective residences/homes using electronic media in the form of smartphones connected to the internet network. This ELearning model is used because the learning process takes place during the covid-19 pandemic and does not allow students to come and gather in class.

\section{Table 2. E-learning Model Learning Process}

\begin{tabular}{|l|l|}
\hline Early Activities & - Admin contact students according to the specified schedule. \\
& $\begin{array}{l}\text { - Admin gives a special phone that will be used for learning through zoom } \\
\text { meeting }\end{array}$ \\
\hline - Students are welcome to join zoom meeting
\end{tabular}

The use of the e-learning model does not diminish and hinder the learning process carried out in these nonformal schools. E- learning is implemented by using the zoom meeting application on smartphones connected to the internet network. Thus, the learning process during the covid-19 pandemic will 


\section{International Journal of}

Advanced Multidisciplinary Scientific Research (IJAMSR) ISSN:2581-4281

continue and do not stop or hinder students in the formation of creativity, as well as children's imagination through drawing lessons at the nonformal school OHAYO Drawing School Surakarta.

\section{Advantages and Disadvantages of E-Learning}

E-learning is information and communication technology to enable students to learn anytime and anywhere (Dahiya, 2012). Thus, the elearning model can make it easier for students to do learning activities anywhere according to their place of residence.

The use of e-learning models in drawing learning activities at OHAYO Drawing School Surakarta is effective and does not reduce children from expression and channel talents and hobbies through drawing activities. With the e-learning model, it will make it easier for students to continue to carry out the learning process without coming to school. This is in line with the opinion of Elyas (2018) in his journal that by e-learning students do not need to travel to where the lesson is delivered, elearning can be accessed from anywhere who has access to the Internet. In fact, with the development of mobile technology (with laptops, even certain types of mobile phones), it is easier to access e-learning (Elyas, 2018:6).

The advantages of learning models like this are the level of independence of students to be better and their communication engineering skills that show encouraging progress. With elearning the knowledge development process takes place not only in the classroom but with the help of smartphone equipment and networking, students can be actively involved in the learning process

The use of e-learning models to learn is not separated from the shortcomings. Especially for use in the drawing learning process. The data obtained in the field from the observations is that teachers/mentors have difficulty directing students in the process of drawing manga comics, where the process of drawing manga comics there are stages that must be understood by students, difficulties among others (1) Teachers can't see directly the drawing process, (2) Submissions made by teachers are still difficult for students to receive due to the lack of signal in the area. (3) Lack of interaction between students and teachers that causes students to understand to the maximum the material conveyed by the teacher. This is in line with Elyas's opinion (2018) in his journal that the lack of e-learning is a lack of 
interaction between teachers and students or even between the students themselves. This lack of interaction can slow down the formation of values in the process of learning and teaching, not all places are available internet facilities.

\section{Results of the creation of student manga comics}

The form of the students' work that has been obtained from the field during the study is in the form of manga images that are applied to a comic strip story. This discussion discussed the work of several students who did learning in manga classes at OHAYO Drawing School Surakarta. The work taken to be discussed is from the results of the test increase from elementary level two to elementary three.

\section{Fransisca Manga Comics}

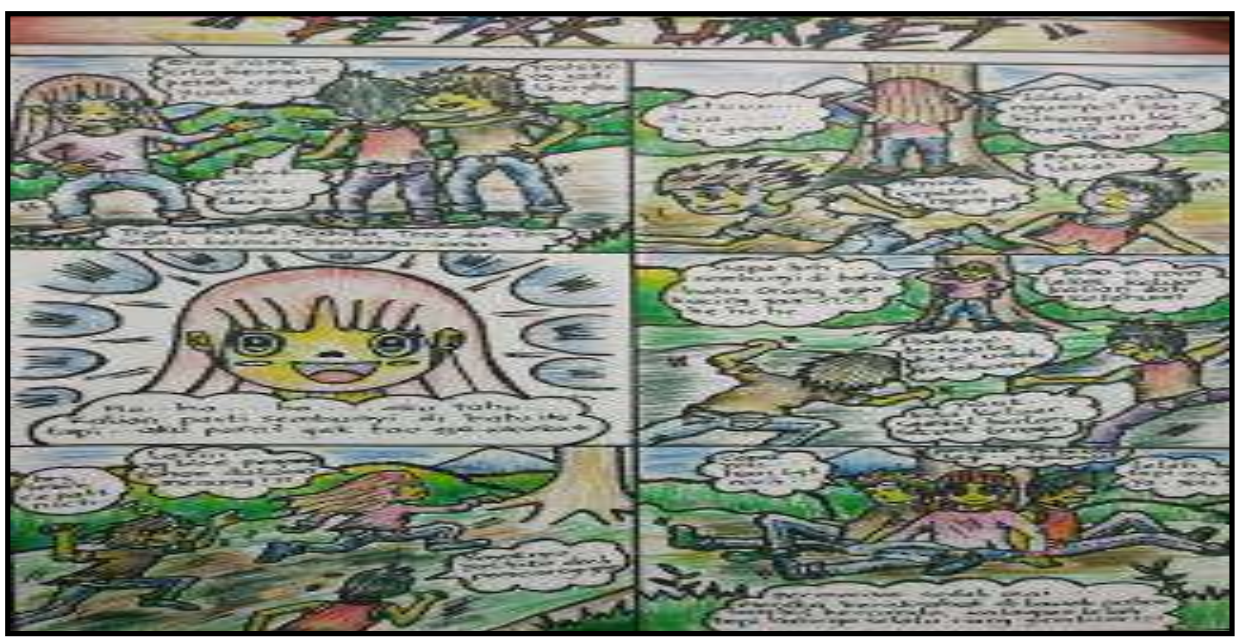

Picture 1. Fransisca's work. (Source: OHAYO Drawing School Surakarta Documentation, 2020)

Title : Hide and Seek

Media : Pencil, color pencil, marker on paper

Size $\quad: 21,0 \times 29,7 \mathrm{~cm}(\mathrm{~A} 4)$ 
Vol 3, Issue 10, 2020 Imfact Factor:2.58 DOI: https://doi.org/10.31426/ijamsr.2020.3.10.3814

J A M S R

\section{International Journal of \\ Advanced Multidisciplinary Scientific Research (IJAMSR) ISSN:2581-4281}

\section{Prischa Manga Comics}
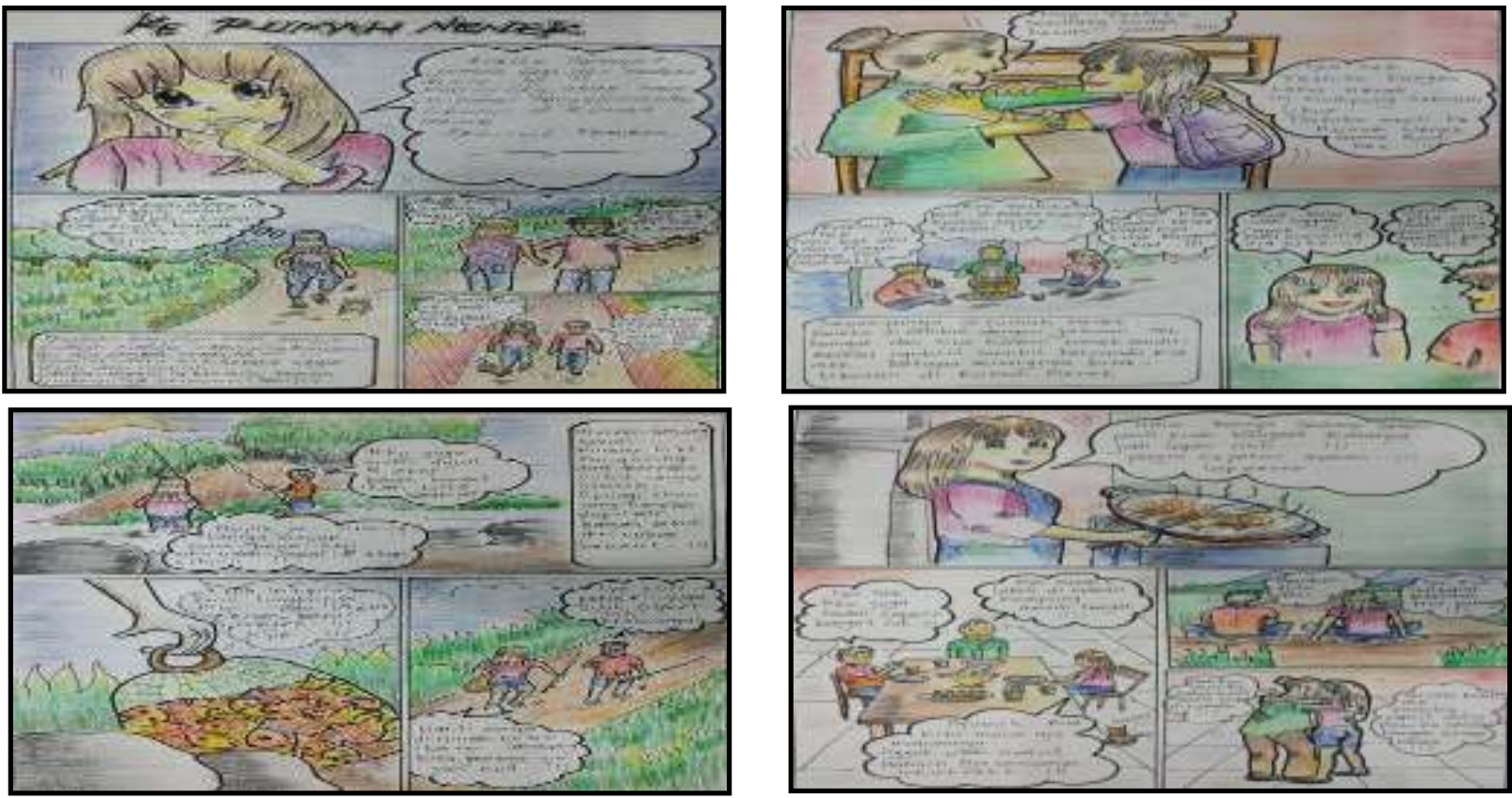

Picture 2. Prischa's work. (Source: OHAYO Drawing School Surakarta Documentation, 2020)

Title : To Grandma's House

Media : Pencil, color pencil, marker, and drawing pen on paper

Size $\quad: 21.0 \times 29.7 \mathrm{~cm}(\mathrm{~A} 4)$

Sean Manga Comics

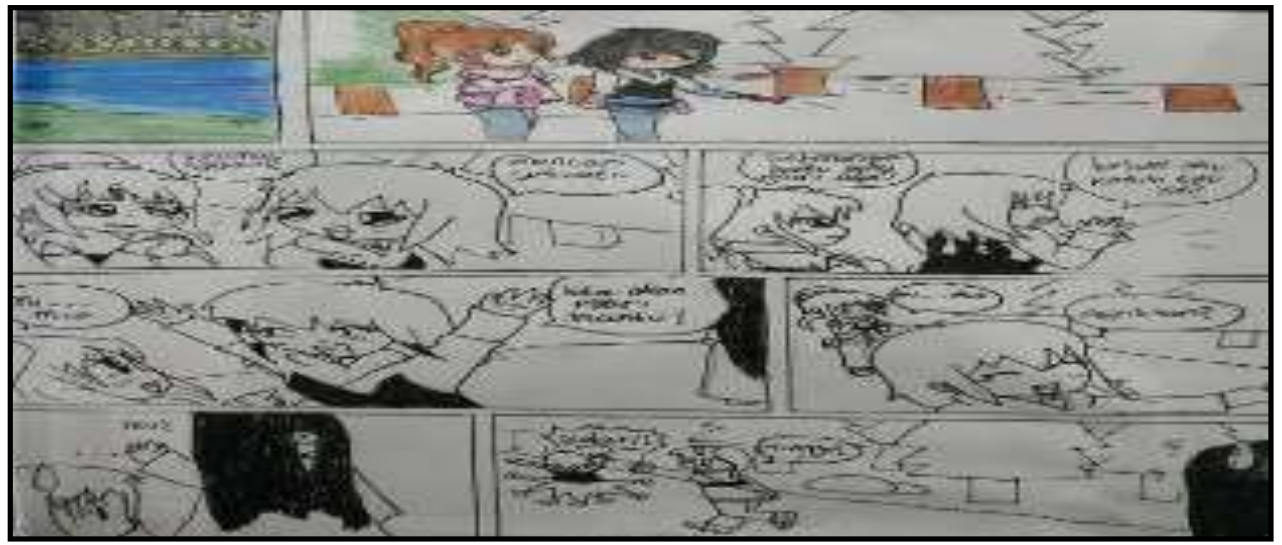

Picture 3. Sean's work. (Source: OHAYO Drawing School Surakarta Documentation, 2020)

Title : Searching for Something

Media : Pencil, color pencil, marker on paper

Size $\quad: 21,0 \times 29,7 \mathrm{~cm}(\mathrm{~A} 4)$ 


\section{International Journal of}

Advanced Multidisciplinary Scientific Research (IJAMSR) ISSN:2581-4281

\section{Conclusion}

Based on the description resulting from descriptive qualitative research, it can be summed up as follows:

Learning to draw manga comics that are performed in the nonformal school OHAYO Drawing School Surakarta is using the elearning method. Learning using e-learning methods is suitable for use during the covid-19 period which does not allow students to come and meet in person with teachers/mentors.

The learning process using the e-learning method includes three stages, namely the initial activity, the core activity, and the closing activity. The initial activity is the preparation of the learning process by preparing several components and learning tools. The core activities are the process of implementing learning in the form of providing materials by teachers/mentors to students and the assignment of drawing manga comics. The closing activity is evaluation. Evaluation is done by the way the teacher comments on the work made by the student.

The use of e-learning models makes it easy for children to still be able to learn to draw manga comics and channel talents and hobbies through nonformal schools. So, during the covid-19 pandemic does not detract from the process of working. Thus, the creativity possessed by the child will continue to grow and develop. Furthermore, providing motivation and freedom to students through a zoom meeting is very influential which is to encourage the spirit of students, students will be confident and not ashamed to express themselves so that the creativity that the child will form and develop well.

\section{Advice}

Learning using e-learning methods has its advantages and disadvantages. If the e-learning model is used for a long period in Indonesia, it is expected that the government will develop and improve the smooth running of internet signals. Especially areas that are minimal to reach such signals. Thus children who are away from the city will easily obtain and access signals to learn online. So the e-learning model will run smoothly throughout Indonesia and not make it difficult for children /students to access internet signals. 


\section{References}

1) Barbot, B., Besancon, M., \& Lubart, T.I. Assessing creativity in the classroom. The Open Education Journal. (2011). 4, 58-66. https://doi.org/10.2174/1874920801104010 058.

2) Brenner, Robin E. Understanding Manga and Anime. (2007). Greenwood Publishing Group

3) Dahiya, S. Jaggi, S. Chaturvedi, K.K. Bhardwaj, A. Dkk. An eLearning System for Agricultural Education. Indian Research Journal of Extension Education. (2016). 12(3), pp.132-135.

4) Daryanto. Media Pembelajaran: Peranannya Sangat Penting Dalam Mencapai Tujuan Pembelajaran. (2010). Yogyakarta: Gava Media

5) Elyas, A H. PENGGUNAAN MODEL PEMBELAJARAN E-LEARNING DALAM MENINGKATKAN KUALITAS PEMBELAJARAN. Jurnal Warta Dharmawangsa. No.56. ISSN : 1829 7463. (2018). Medan: Dharmawangsa University

6) Fathurrohman, Muhamad. Belajar dan Pembelajaran Modern Konsep Dasar, Inovasi dan Teori Pembelajaran. (2017). Yogyakarta: Garudhawaca.

7) Iryanti, E V. Jazuli M. MEMPERTIMBANGKAN KONSEP PENDIDIKAN. Jurnal Harmonia Vol.2 No.2. (2001). Semarang: UNNES

8) Munandar, Utami. Pengembangan Kreativitas Anak Berbakat. (1995). Jakarta: P.T Rineka Cipta
9) Moleong, J. Lexy. Metodologi Penelitian Kualitatif Edisi Revisi. (2017). Bandung: PT Remaja Rosdakarya

10) Sutarto, Joko. Pendidikan Nonformal (Konsep Dasar, Proses Pembelajaran \& Pemberdayaan Masyarakat). (2007). Semarang: UNNES PRESS.

11) Sutopo, H.B. Motodologi Penelitian Kualitatif Dasar Teori dan terapannya dalam penelitian. (2006). Surakarta: UNS.

12) Sugiyanto. Model-Model Pembelajaran Kooperatif. (2008). Surakarta : Depdikbud

13) Utomo Budi, Kamsijo. Silabus, Handout, dan Media Pembelajaran Strategi Pembelajaran Seni Rupa. (2009). Semarang

14) Willemsen, $R$ H. Schovers, E M. \& Kroesbergen, $H E$. The Structure of Creativity in Primary Education: An Empirical Confirmation of the Amusement Park Theory. Journal of Creative Behavior. (2019). Netherlands

15) Widiyastuti Endang. Peningkatan Kemampuan Menggambar Bebas Siswa B1 Melalui Strategi Pembelajaran Pemberian Motivasi. Jurnal Harmonia Vol.12 No.2. (2012). Semarang:UNNES

16) Winkel, W.S. Psikologi Pengajaran. (1991). Jakarta: Grasindo

17) Yamin, M.H. \& Maisah. Manajemen Pembelajaran. (2009). Jakarta: GP Press 